\title{
Sports Mega-Event Sponsorship: The Impact of FIFA Reputation and World Cup Image on Sponsor Brand Equity
}

\author{
Mariana Guará Rocha Coelho ${ }^{1}$ \\ João Guilherme Barbosa de Amorim ${ }^{1}$ \\ Victor Manoel Cunha de Almeida ${ }^{1}$
}

Universidade Federal do Rio de Janeiro, Rio de Janeiro, RJ, Brazi ${ }^{1}$

Received 13 June 2018. This paper was with the authors for two revisions. Accepted 18 March 2019. First published online 12 April 2019.

Yeda Swirski de Souza was the associate editor for this article.

Editorial assistant: Luciane Kato Kiwara

Editor-in-chief: Carlo Gabriel Porto Bellini 


\begin{abstract}
The present study investigates the influence the organizing body's reputation has on the image of a sports mega-event and on the mega-event sponsors' consumer-based brand equities. The study's main theoretical references are Associative Network Theory (Collins \& Loftus, 1975) and Schema Theory (Axelrod, 1973), both about the functioning of the human memory. The research was carried out during the 2014 FIFA World Cup in Rio de Janeiro. Brazilians and foreigners who attended the 2014 FIFA Fan Fest on Copacabana Beach were surveyed through a nonprobabilistic sampling, and 1,973 questionnaires were collected. Data analysis was performed using Exploratory Factor Analysis (EFA) and Confirmatory Factor Analysis (CFA). We verified the reliability, convergent, discriminant, and nomological validity of the constructs. In order to test the substantive hypotheses, we applied Structural Equation Modeling (SEM) using an Asymptotic Distribution-Free (ADF) technique. The empirical results suggest that FIFA's reputation influences the image of the FIFA World Cup, but may not directly influence the sponsors' consumer-based brand equities. We also verified that the perception of fit between the mega-event and the sponsor plays a partial mediating effect on the relationship between the image of the mega-event and the sponsor's brand equity.
\end{abstract}

Key words: sports marketing; sports sponsorship; mega-events; reputation; brand equity. 


\section{Introduction}

Football (soccer) is the most popular sport worldwide and the Fédération Internationale de Football Association (FIFA) is the governing body responsible for organizing major international football events. FIFA is a non-profit organization with members from 209 countries and territories. The entity pursues its objectives through several activities, therefore holding a wide list of stakeholders ranging from national to continental football associations, worldwide fans and professionals, governments, media companies, and sponsors (Pielke, 2013). FIFA's revenue was 5.7 billion dollars between 2011 and 2014, 90\% of which was a result of activities related to its international events, such as the 2014 FIFA World Cup and the 2013 Confederations Cup. Out of the 5.1 billion dollars derived from international events, $47 \%$ came from the 2014 World Cup broadcasting rights and 31\% resulted from the event's marketing and sponsorship deals (FIFA, 2015).

Right before the 2013 Confederations Cup Brazil witnessed a series of protests that culminated in demonstrations involving more than 1.4 million participants in 130 cities on June 20, 2013 (Moreno, 2013). Among the popular outcries, and despite Brazil's historical and profound relationship with football and its major global event, was the questioning of Brazil as the FIFA World Cup host country, as well as the event's organization and management practices and FIFA's own reputation (Fonseca, 2013).

Sports mega-events have become a research topic in different fields of study in recent years with some authors approaching issues such as mega-events' social, cultural, and economic impact at a local level, with regards to the host society, and also at a global level (Horne, 2015; Horne \& Manzenreiter, 2006; Kaplanidou et al., 2013; Kesenne, 2012; Roche, 2000). Some have tackled issues related to the ethics and governance of organizing entities (Lenskyj, 2000; Pielke, 2013), while others have assessed the potential benefits for the image countries, cities, and private companies derive from association with mega-events (Heslop, Nadeau, O'Reilly, \& Armenakyan, 2013; Nufer \& Bühler, 2010; Weszka, 2011; Woisetschläger \& Michaelis, 2012).

Specifically, in the marketing domain, research on the effects of company association with sports mega-events through sponsorship has received special relevance. Mega events such as the Olympic Games and the FIFA World Cup are considered to be unique options for companies seeking global sponsorship strategies, as they offer the possibility of brand association with the sport and a high visibility property with which the public is deeply connected (Madrigal, Bee, \& LaBarge, 2005).

Despite the rise of a corporate marketing logic in which companies perceive the increasing importance of maintaining good relationships and good standing with a broader group of stakeholders (Balmer, 2011) and of authors pointing to questions about the reputation of organizations (Horne \& Manzenreiter, 2006; Kesenne, 2012; Pielke, 2013), the reputation of the organizations behind sports mega-events has not been extensively investigated in empirical studies on sponsorship. Specifically, in the football context, there is only one empirical study found in the literature that relates perceptions about FIFA with the image of the FIFA World Cup. M. 
Walker et al. (2013), in a research conducted during the 2010 FIFA World Cup in South Africa, suggested that the perception of FIFA as a socially responsible organization influences the image of the mega-event.

In such a context, the academic contribution of this study is broadening the body of knowledge regarding sports sponsorship in the context of mega-events, more specifically by investigating: (a) if the reputation of the organizing entity impacts the sponsors' brand equities and the megaevent's image; (b) if the mega-event's image influences the sponsors' brand equities; (c) if the perception of fit between the mega-event and the sponsors exerts a mediating effect on the relationship between the mega-event's image and the sponsors' brand equities.

\section{Theoretical Background}

\section{Sports mega-event image}

Mega-events enable transmission of promotional messages to billions of people through television and other means of communication (Roberts, 2004) since the attraction of the media constitutes one of their main characteristics. Although the definitions of mega-events typically do not imply a specific theme and therefore include both sports and non-sports events (Heslop et al., 2013; Jago, Dwyer, Lipman, Lill, \& Vorster, 2010; Müller, 2015; Roche, 2000), since the 1980s sports mega-events have become a synonym for this category of events (Lenskyj, 2015). Overall, a sports event image may be defined as a set of "mental representations sport tourism participants have about the organization, environment, physical activity, socialization, fulfillment, and emotional involvement with the event" (Kaplanidou \& Vogt, 2006, p. 5) or "cumulative interpretation of meanings or associations attributed to events by consumers" (K. Gwinner, 1997, p. 147). K. Gwinner (1997) proposes that the event's image is shaped by: (a) the type of event; (b) characteristics of the event, such as the scope, its history, venues, and sponsorship; and (c) personal aspects.

Given that events may be considered as products, some authors have been treating the image of an event in an equivalent manner to that of the image of a brand (Grohs, Wagner, \& Vsetecka, 2004; Kaplanidou \& Vogt, 2006; Shin, Lee, \& Perdue, 2018). Studies on the aspects of event image are becoming more relevant to the fields of marketing and tourism as the event image may be transferred to another entity, similar to what occurs with host cities (Heslop et al., 2013) and sponsors (K. Gwinner, 1997; Nadeau, O'Reilly, \& Heslop, 2013). This happens through the transference of associations comprising that image (K. Gwinner, 1997).

Although unlikely (K. P. Gwinner \& Eaton, 1999), the transfer of the image or associations from the host city or sponsor to the mega-event is also possible (Heslop et al., 2013). The possibility of the influence of the sponsor's image on the event's image is more common when the event is small and unknown (M. Walker, Hall, Todd, \& Kent, 2011). 


\section{Sports mega-event sponsorship}

Given the behavioral and lifestyle changes and the development of means that allow for consumer marketing message avoidance, the market has realized a need for bringing brands to consumers with an objective of providing them with a friendlier experience. In this context, nontraditional indirect-marketing tools such as viral marketing, buzz, and product placement have developed and gained relevance in the last decades, with sponsorship becoming a tool of the greatest prominence and participation (Cornwell, 2008).

Sponsorship may be defined as the "provision of assistance either financial or in kind to an activity by a commercial organization for the purpose of achieving commercial objectives" (J. A. Meenaghan, 1983, p. 9). Due to its worldwide popularity, sports sponsorship provides an opportunity for image exposure and for developing a positive relationship between the image of a certain brand and several kinds of properties, offering the possibility of transferring attributes and other associations to the sponsor's brand (Farrelly, Quester, \& Burton, 2006).

The increased interest in the sponsorship of mega-events, such as the FIFA World Cup and the Olympic Games, was not only due to the increase in their audiences, but also to the potential for global communication of these events, overcoming cultural and language barriers. In a moment when multinational companies were looking for ways to globalize their markets and offerings, sports mega-events provided an attractive communication platform (T. Meenaghan, 1991). Sponsoring companies seek to take advantage of the link established with the mega-event through the sponsorship agreement in an attractive context, such as the sport's context, to transfer the positive image of the event to the brand (Nufer \& Bühler, 2010).

Organizers of mega-events fund their events by selling sponsorship, broadcasting rights, and licensing of official products. The sponsorship revenue is the second largest source of income for these organizations, being surpassed only by broadcasting rights revenue (FIFA, 2015; International Olympic Committee [IOC], 2013). Both FIFA and the International Olympic Committee developed their sponsorship programs in the 1980s, including the concept of category exclusivity and different commercial rights packages for their organizations and mega-events sponsorship contracts (Chadwick \& Burton, 2011).

\section{Fit}

The concept of congruence, although lacking a single and widely accepted nomenclature or definition, has been discussed in advertising and marketing literature since the 1980s. The theoretical discussion about this concept is related to the idea that people develop a perception that certain things match each other, while others clash. In consequence, this perception would influence their response to the stimuli coming from a marketing strategy that uses brand extensions, celebrity endorsement, co-branding, product placement, and sponsorship (Fleck \& Quester, 2007). 
Studies on the impact perception of congruence has on sponsorship results consider the psychological mechanisms underlying audience response to the sponsorship (Deitz, Myers, \& Stafford, 2012). These are mainly based on two theories originating from Cognitive Psychology: Associative Network Theory and Schema Theory (Drengner, Jahn, \& Zanger, 2011). According to Associative Network Theory, an individual's memory is organized in such a way that the pieces of information are completely interconnected like the knots in a net. Each piece of information is linked to several other pieces of interconnected information. The strength of the connecting knots varies according to the importance of that connection for the comprehension of a concept (Collins \& Loftus, 1975).

Schema Theory also presupposes that information is interconnected in human memory. Information is saved within schemes composed of preexisting suppositions about the ways the world operates (Singer, 1968). When individuals receive new information, they try to fit it into a scheme relying on the previously acquired facts and interpretations (Axelrod, 1973).

More specifically, in the sponsorship field, research on the influence perception of congruence between sponsor and sponsorship property has on consumer response include, for example, studies related to the sponsorship of causes (Rifon, Choi, Trimble, \& Li, 2004), football clubs (Amorim \& Almeida, 2015), university sports programs (Deitz et al., 2012), and mega-events (Biscaia \& Rocha, 2018; Ko, Chang, Park, \& Herbst, 2017).

\section{Corporate reputation}

Corporate reputation may be defined as "a relatively stable, issue specific aggregate perceptual representation of a company's past actions and future prospects compared against some standard" (K. Walker, 2010, p. 370); or "a collective assessment of a company's ability to provide valued outcomes to a representative group of stakeholders" (Fombrun, Gardberg, \& Sever, 2000, p. 243); or even "a set of cognitions based on both beliefs and attitudes in the mind of the general public or in various specific sub-groupings therefrom" (Clardy, 2012, p. 300). This collective perception regarding an organization may vary among stakeholder groups and might impact group attitudes towards this organization (Balmer \& Greyser, 2006).

As it represents the perception of several individuals (Fombrun et al., 2000), the reputation can be more or less clear according to the homogeneity of the perceptions regarding a corporation within a group (Sjovall \& Talk, 2004). Direct contact or the observation of an organization's actions contribute to the development of perceptions by an individual, although perceptions are also shaped based on exposure to others' impressions and opinions, such as those posted in the press or on social networks (Sjovall \& Talk, 2004; Zheng, Liu, \& Davison, 2018).

\section{Brand equity}

Literature regarding brand equity is ample and fragmented. First, brand equity can be measured from two perspectives: the financial one, which serves the purposes of accounting and corporate 
transactions; and the strategic one related to the perceptions about a brand based on the consumer's perspective (Christodoulides \& de Chernatony, 2010; Oliveira \& Luce, 2012).

Consumers' perspectives and their responses to brand offers have a direct impact on revenues and market share, therefore, consumer-based brand equity (CBBE) precedes financial brand equity, or firm-based brand equity (Christodoulides \& de Chernatony, 2010; Oliveira \& Luce, 2012). CBBE may be defined as the "differential effect of brand knowledge on the consumer's response to the marketing of the brand" (Keller, 1993, p. 8). When a consumer responds differently to the same product attributes and marketing mix, the differential effect can be attributed to brand equity (Yoo \& Donthu, 2001).

Important theoretical postulations concerning CBBE development highlight, among other dimensions, that brand associations influence this construct (Aaker, 1998; Keller, 1993). Associations may be attributes related or not to the product or service offered by the brand; functional, experiential, and symbolic benefits; or general attitudes towards the brand. These brand associations may be of a primary nature, i.e., attributes, beliefs, and attitudes directly related to a specific brand; or secondary, transferred in the consumer's mind from the connection of the brand with another entity. These may be attributes linked to a brand's manufacturing company, its country of origin, its distribution channel, an endorsing celebrity, or an event (Keller, 1993).

\section{Hypothesis and Theoretical Framework}

\section{Sports mega-event organizer reputation and mega-event image}

Reputation refers to perceptions, associations, and judgements that stakeholders hold about an organization (Balmer \& Greyser, 2006). If a corporate brand can transfer secondary associations to a product brand (Raggio \& Leone, 2007), it is possible to establish a direct link between the mega-event organizing entity, who owns the rights to the mega-even brand, and the mega-event itself (Grohs, 2016; Weszka, 2011). Therefore, the sports mega-event might have its brand image loaded with associations related to its proprietary entity, leading to the first research hypothesis.

H1: The positive reputation of the mega-event organizer influences the mega-event image perception.

\section{Sports mega-event organizer reputation and sponsor brand equity}

When looking for a link with a sport property, sponsors aim to achieve brand visibility and transfer positive associations (Walliser, 2003). The improvement of a sponsor's corporate reputation is also mentioned in the literature as one of the sponsorship objectives, which reinforces the importance of such associations (Dolphin, 2003). More visibility and positive associations might improve brand equity from the consumer's perspective (Buil, Martínez, \& Chernatony, 2013). Nevertheless, when linking a sponsoring brand with a mega-event, the 
sponsor also becomes linked with the sport mega-event organizer. Taking this into consideration, the second research hypothesis is:

H2: The positive mega-event organizer's reputation influences the mega-event sponsor's brand equity perception.

\section{Mega-event image and sponsor brand equity}

One of the main objectives of sports sponsorship is to use the property's image to gain benefits in terms of brand visibility and image (Farrelly et al., 2006). The visibility achieved by establishing a partnership with a property, such as a sports mega-event, might increase brand awareness and recognition. Several studies adopted brand awareness and brand recognition as dependent variables (Walliser, 2003), relating both concepts to gains regarding consumer-based brand equity (Buil, Chernatony, \& Martínez, 2008; Christodoulides \& de Chernatony, 2010; Pappu, Quester, $\&$ Cooksey, 2005).

According to a number of theoretical (Christodoulides \& de Chernatony, 2010) and empirical studies (Buil et al., 2008; Pappu et al., 2005; Yoo \& Donthu, 2001), greater brand awareness and better brand image are related to consumer-based brand equity gains. Hence, the third research hypothesis is:

H3: The positive mega-event image influences the perception of the mega-event sponsor's brand equity.

\section{Congruence mediating effect}

According to theories that frame the concept of congruence, a sponsor relationship perceived as congruent follows information schemes shaped by memory of past experiences and judgments (Deitz et al., 2012; J. Koo \& Lee, 2018; Weeks, Humphreys, \& Cornwell, 2018). Establishing and activating a congruent sponsor relationship might therefore strengthen associations between the sponsor and the sports property (Biscaia \& Rocha, 2018; Cornwell, 2008; Wang, 2017). Regardless of its functional or symbolic origin, congruence perception may lead to more beneficial sponsorship results, influencing relations as a mediating variable between the sponsor's motivations and the responses to the sponsorship (Deitz et al., 2012); between property identification and attitudes towards the sponsor (K. Gwinner \& Bennett, 2008); and between property identification and the sponsor's brand equity (Amorim \& Almeida, 2015).

In this sense, it is established that: (a) the objectives of the sponsorship are to improve brand awareness rates and brand equity (Cornwell \& Maignan, 1998; Walliser, 2003) and that these effects are related to the sponsor's consumer-based brand equity (Aaker, 1998; Keller, 1993); (b) the perception of congruence between the sponsor and the sponsored property might contribute to the sponsor's recognition (G.-Y. Koo, Quarterman, \& Flynn, 2006) and to the transferring of the property's positive associations (Cornwell, 2008); and (c) the perception of congruence might 
act as a mediator between sponsorship antecedents and outcomes (Amorim \& Almeida, 2015). As a result, the last research hypothesis is:

H4: The perception of congruence between the mega-event and the sponsor has a mediating effect in the relationship between mega-event image and the sponsor's brand equity.

Figure 1 displays the conceptual model and synthesizes the study's substantive hypotheses.

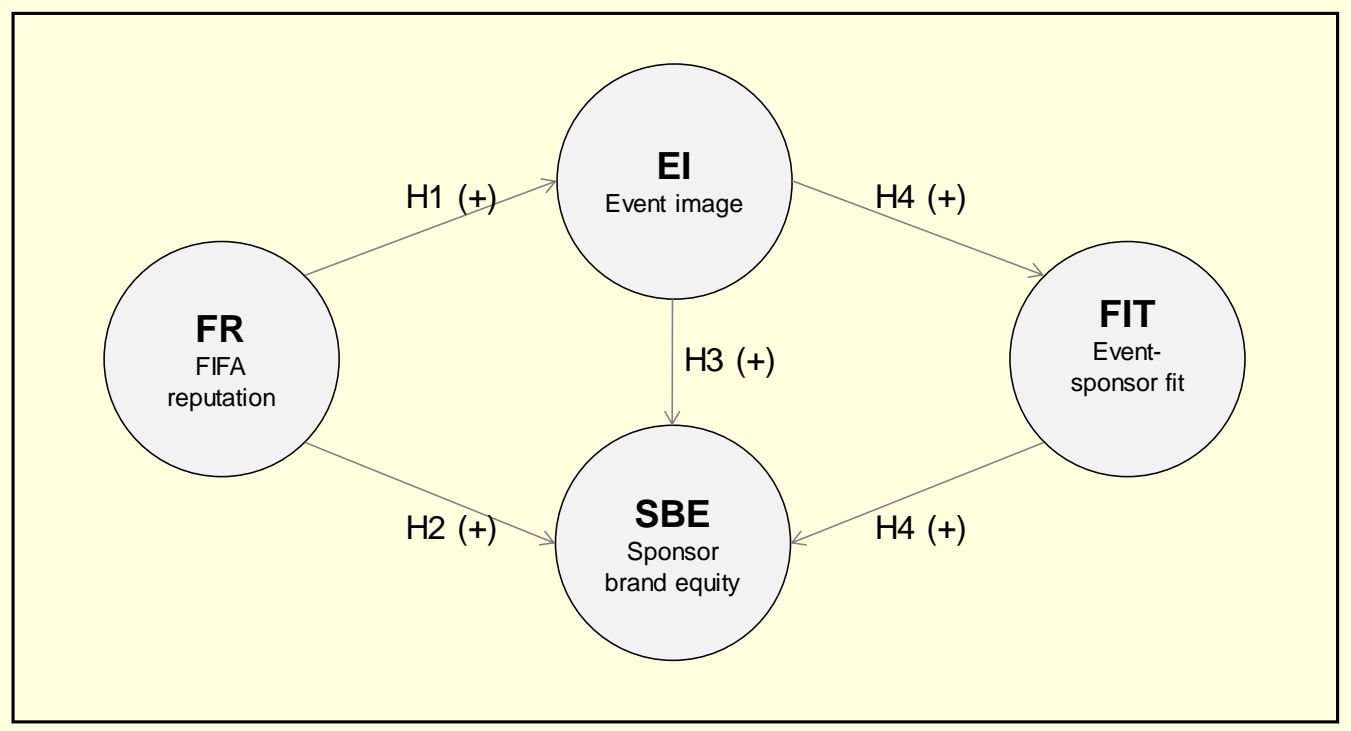

Figure 1. Theoretical framework

\section{Method}

The decision regarding the research scope was to focus in this study on the influence of FIFA's reputation on the 2014 FIFA World Cup and its sponsors, Coca-Cola and Adidas, two of the brands with the highest level of brand awareness worldwide. It is worth mentioning that even though these brands denote different levels of relationship with sports, their selection did not imply or expect any sort of moderation effect. The analysis involved the perspective of mega-event spectators, host country residents, and foreign tourists participating in the 2014 FIFA World Cup at the FIFA Fan Fest in Rio de Janeiro. Interviews were conducted in Portuguese, English, and Spanish. At the end, a decision was made to disregard antecedents concerning the sponsor's brand equity in the overall context of sports sponsorship other than the mega-event organizer's reputation, the mega-event image, and the perception of congruence between sponsor and sponsored property. 


\section{The 2014 FIFA World Cup and the FIFA Fan Fest in Rio de Janeiro}

Rio de Janeiro was one of the 12 host cities for the 2014 FIFA World Cup and it held 7 matches at the Maracanã Stadium with a total of 519,153 spectators (Carpes, 2014). Rio de Janeiro also hosted an edition of the FIFA Fan Fest, a public viewing of the World Cup matches (Becker, Kautsky, \& Widholm, 2014). During the preparation for the 2010 World Cup, FIFA defined the FIFA Fan Fest concept as a platform capable of providing a unique experience for football fans. The event includes the broadcasting of all matches on the giant high-quality screens (FIFA, n.d.a). In Rio de Janeiro, the FIFA Fan Fest had the capacity to accommodate 20,000 people and was visited by more than 800,000 people during the event (Carpes, 2014; FIFA, n.d.b).

\section{The sponsors}

Coca-Cola and Adidas were the brands selected for this study. Coca-Cola is considered to be a benchmark for the sponsorship market (IEG Sponsorship Report, 2008) having sponsored the Olympic Games since 1928 and holding decades of history with the World Cup, always standing in the highest position of sponsorship and part of the group named as FIFA Partners (FIFA, n.d.c). Adidas, which also belongs to the FIFA Partners category, was chosen for the study because of its role as a sponsor as well as a supplier of sports goods. Given its sponsorship portfolio exclusively focused on sports (Adidas, n.d.) and its history with the World Cup since 1970 (Adidas, 2005), Adidas presents an evident functional congruence with this kind of property (J. Koo \& Lee, 2018; Pappu \& Cornwell, 2014).

\section{Design and procedures}

In order to assess the mega-event corporate reputation, we adopted the Reputation Quotient (RQ) scale developed by Fombrum, Gardberg, and Server (2000), but reduced it to fit the dimensions applicable to a non-governmental organization. The image of the mega-event was examined using a scale applied to a study that measured the image of the Beijing 2008 Olympic Games (Event Image - EI) (Nadeau, O'Reilly, \& Heslop, 2011). The Sponsor-Event Fit (FIT) scale conceived by Speed and Thompson (2000) was the choice for assessing the construct of perceptual congruence between the brand and the sponsored property. This scale has been tested in a number of studies dealing with sports sponsorship (Close \& Lacey, 2013; Deitz et al., 2012; Grohs \& Reisinger, 2014; Ko et al., 2017; Olson, 2011). The sponsor's consumer-based brand equity was assessed by applying the Overall Brand Equity (OBE) scale by Yoo and Donthu (2001), already used to measure corporate brand equity. It was necessary to do Portuguese and Spanish back-translations with English for the Reputation Quotient (RQ) and Event Image (EI) scales, which had not been previously used in the Brazilian context (see Appendix).

To mitigate the eventual learning effect resulting from the double use of the Overall Brand Equity and Sponsor-Event Fit scales in the same questionnaire, half of the questionnaires presented the items about Adidas before the items about Coca-Cola and half the other way around. This option was made because the responses regarding one of the sponsors could generate a bias in the 
responses to the other. Since versions of the questionnaire were generated in three different languages (Portuguese, English, and Spanish) and each language had two versions (starting with Coca-Cola and starting with Adidas), six versions of the questionnaire were generated in total.

\section{Sample and data collection}

Data was collected using a non-probabilistic sample during eleven competition days, from the first stage until the third-place playoff. 2,002 fans were interviewed after the questionnaire was pre-tested. Respondents were randomly selected, following the research prerequisite criteria. A decision was made not to proceed with Brazilian fan interviews after the country was eliminated from the competition in the semi-finals.

\section{Analysis and substantive hypothesis testing}

The exploratory factor analysis (EFA) was performed using SPSS software, version 18. Factor extraction followed the Principal Axis Factor method with Oblimin Rotation. The MSA was used to perform EFA fit analysis, all according to Hair, Black, Babin, and Anderson (2010). AMOS software version 17 was used for the Confirmatory Factor Analysis (CFA). The variables' multinormality was analyzed according to an independent, item-by-item, kurtosis and multivariate kurtosis. It was not possible to assure data multinormality, so we opted to adopt CFA with an Asymptotic Distribution Free (ADF) method, which does not establish the premise of normal data distribution (Kline, 2005). The measurement models for each scale were evaluated using the following quality of fit indices: $\chi 2 ; \chi 2 / g 1$; GFI; RMSEA; PCLOSE; and CFI. We evaluated construct reliability by using the Construct Reliability (CR) indicator. Convergent validity was checked by each construct standardized coefficient and the Average Variance Extracted (AVE), and the discriminant validity by correlation analysis between the constructs and the test postulated by Fornell and Larcker (1981). The nomological validity was examined through the significance and signs of the relations.

We performed a substantive hypothesis test using Structural Equation Modeling (SEM), which enables estimating dependent relationships, latent variables, and measurement error. To test the hypotheses, we examined conceptual model hypothesized paths. A mediation test was also performed according to the Four Steps Approach proposed by Baron and Kenny (1986) followed by the Sobel Test (1982) and bootstrapping.

\section{Results}

Out of the 2,002 questionnaires collected, 29 were eliminated because of mistakes or missing answers, leading to a final number of 1,973 valid questionnaires. From those, 523 were responded to by Brazilian men (26\% of the total sample) and 548 by Brazilian women (28\%). Foreign men accounted for $25 \%$ of the total sample (492 respondents) and foreign women for 21\% (410 respondents), which indicates a balanced sample (See Table 1). 
Table 1

\section{Sample profile}

\begin{tabular}{lccccc}
\hline & \multicolumn{2}{c}{ Total } & \multicolumn{2}{c}{ Brazilian residents } & Foreign visitors \\
\cline { 2 - 6 } Variable & $\mathrm{F}$ & $\mathrm{F} \%$ & $\mathrm{~F}$ & $\mathrm{~F} \%$ & $\mathrm{~F}$ \\
\hline Respondents & 1973 & $100 \%$ & 1071 & $54.3 \%$ & 902 \\
\hline Male & 1015 & $51.4 \%$ & 523 & $48.8 \%$ & 492 \\
Female & 958 & $48.6 \%$ & 548 & $51.2 \%$ & 410 \\
\hline Brazilians & 1017 & $51.5 \%$ & 1005 & $93.8 \%$ & 12 \\
Foreigners & 956 & $48.5 \%$ & 66 & $6.2 \%$ & 890 \\
\hline $\begin{array}{l}\text { Participation in previous editions of FIFA } \\
\text { World Cup }\end{array}$ & 167 & $8.5 \%$ & 22 & $2.1 \%$ & 145 \\
\hline $\begin{array}{l}\text { Participation in previous editions of the } \\
\text { Olympic Games }\end{array}$ & 251 & $12.7 \%$ & 123 & $11.5 \%$ & 128 \\
\hline $\begin{array}{l}\text { Approval of Brazil as the host country for } \\
\text { FIFA World Cup }\end{array}$ & 1539 & $78.0 \%$ & 722 & $67.4 \%$ & 817 \\
\hline Questionnaires in Portuguese & 1025 & $52.0 \%$ & 1011 & $94.4 \%$ & 14 \\
Questionnaires in English & 513 & $26.0 \%$ & 27 & $2.5 \%$ & 486 \\
Questionnaires in Spanish & 435 & $22.0 \%$ & 33 & $3.1 \%$ & 402 \\
\hline
\end{tabular}

The scales adopted underwent an Exploratory Factor Analysis. The analysis of the resulting matrix revealed that instead of forming eleven factors, as the literature on the adopted scales suggested, nine factors were formed in this analysis, with an explained variance of $68.5 \%$. This indicates that the expected dimension distinction for the EI and RQ scales did not occur. The option was to disregard the EI_LB, EI_SB, RQ_VL, RQ_WE, and RQ_SR dimensions due to the inconsistencies found, proceeding with the analysis using items related to the experience evaluation and emotional appeal (EI_EB and RQ_EA) in order to represent the constructs for event image and reputation.

A new EFA was performed using the items selected in the previous stage. The items explained variance increased to $71.6 \%$. There were 6 factors remaining: one for the EI scale, which refers to Experiential Beliefs, two for the OBE scale applied to Coca-Cola and Adidas, one for the FIT scale for each brand studied, and one for the RQ scale related to the Emotional Appeal. All factor loading scores for the items in this EFA were superior to 0.50 . There was no overlap among factors or cross loadings; that is, the items of each one of the scales formed one specific factor, indicating that the extent of common method variance is limited.

A CFA was performed to validate the measuring model. The decision on the estimation technique to be applied was based on histograms of all variables and an item-by-item indicator Kurtosis analysis and multivariate Kurtosis were also conducted. The CR was 147.9, making it unfeasible to support data multinormality. Since this result represents a sample of 1,793 cases, we opted to use ADF. 
We specified the Structural Model with the four constructs of the conceptual model, each with three to five measurement items. The fit indices were: Chi-square of 1,391.63, p-value of 0.000, normalized Chi-square of 4,504, GFI of 0.881 , CFI of 0.823 , RMSEA of 0.042 , and PCLOSE of 1.000. The p-value, $\chi 2 / g 1$, GFI, and CFI indicators remained out of the proposed limits, indicating that the model did not show a proper fit. The model was redefined in order to include a correlation between the scales' errors with their paired items in the scales: OBE_c with OBE_a and FIT_c FIT_a due to their repetition in the questionnaire. The fit indices improved after the re-specification of the model: Chi-square of 1,043.53, p-value of 0.000 , normalized Chi-square of 3,479 , GFI of 0.911, CFI of 0.878, RMSEA of 0.035, and PCLOSE of 1.000. Even though some of the fit indices improved, the $\mathrm{p}$-value, $\chi 2 / \mathrm{gl}$, and CFI remained below the recommended values. Regarding the correlation between scales' errors, it is worth mentioning that some studies explore the importance of considering potential effects resulting from the method (Cole, Ciesla, \& Steiger, 2007) such as high intersection or similarity between the variables with very similar phrasing or the presence of positive and negative items on the same scale (Byrne, Shavelson, \& Muthen, 1989; T. A. Brown, 2003). It is known that items on the same scale usually share variance due to the intersection of meanings. Confirmatory models can be specified to include correlations between error terms that reflect this shared variance (Floyd \& Widaman, 1995) since they typically represent systematic measurement errors resulting from the method (Byrne et al., 1989). It is important to emphasize that this process should not be done only to improve the model's fit indices, but rather be guided by solid theoretical justifications (T. A. Brown, 2003).

The constructs' reliability was checked through the assessment of the CR indicator. The lowest CR, which refers to Event Image, was 0.842, which suggests the reliability of all the constructs in the model. The item EI_EB6 showed a standard coefficient below the expected limit of 0.60, pointing to a satisfactory convergent validity for the remaining scales. Average Variance Extracted (AVE) above 0.50 suggests an adequate convergent validity for all scales, except for EI, which presented AVE $=0.473$.

In sequence, the discriminant validity was analyzed through the observation of correlation coefficients between the constructs, which did not surpass 0.85 . It can be noted that the correlation coefficient squares between the constructs are always below the AVE of each construct, thus supporting the discriminant validity (see Table 2). 
Table 2

Reliability and validity indicators

\begin{tabular}{|c|c|c|c|c|c|c|}
\hline \multirow[b]{4}{*}{ Item } & \multicolumn{6}{|c|}{ Confirmatory factor analysis| CFA - Asymptotically distribution-free } \\
\hline & \multirow{2}{*}{$\begin{array}{l}\text { Event } \\
\text { image }\end{array}$} & \multicolumn{2}{|c|}{ Brand equity } & \multicolumn{2}{|c|}{ Congruence } & \multirow{2}{*}{$\begin{array}{l}\text { FIFA's } \\
\text { reputation }\end{array}$} \\
\hline & & Coca-Cola & Adidas & Coca-Cola & Adidas & \\
\hline & $\mathrm{CR}=.842$ & $\mathrm{CR}=.954$ & $\mathrm{CR}=.928$ & $\mathrm{CR}=.926$ & $\mathrm{CR}=.906$ & $\mathrm{CR}=.925$ \\
\hline El_EB1 & 699 & & & & & \\
\hline EI_EB2 & .729 & & & & & \\
\hline EI_EB3 & .660 & & & & & \\
\hline El_EB4 & .715 & & & & & \\
\hline El_EB5 & .752 & & & & & \\
\hline El_EB6 & $.552^{\mathrm{a}}$ & & & & & \\
\hline OBE_c1 & & .880 & & & & \\
\hline OBE_c2 & & .953 & & & & \\
\hline OBE_c3 & & .939 & & & & \\
\hline OBE_c4 & & .891 & & & & \\
\hline OBE_a1 & & & .842 & & & \\
\hline OBE_a2 & & & .921 & & & \\
\hline OBE_a3 & & & .899 & & & \\
\hline OBE_a4 & & & .832 & & & \\
\hline FIT_c1 & & & & .810 & & \\
\hline FIT_c2 & & & & .887 & & \\
\hline FIT_c3 & & & & .921 & & \\
\hline FIT_c4 & & & & .783 & & \\
\hline FIT_c5 & & & & .820 & & \\
\hline FIT_a1 & & & & & .782 & \\
\hline FIT_a2 & & & & & .852 & \\
\hline FIT_a3 & & & & & .902 & \\
\hline FIT_a4 & & & & & .760 & \\
\hline FIT_a5 & & & & & .753 & \\
\hline RQ_EA1 & & & & & & .869 \\
\hline RQ_EA2 & & & & & & .952 \\
\hline RQ_EA3 & & & & & & .869 \\
\hline
\end{tabular}


Table 2 (continued)

\begin{tabular}{|c|c|c|c|c|c|c|}
\hline \multirow[b]{4}{*}{ Item } & \multicolumn{6}{|c|}{ Confirmatory factor analysis|CFA - Asymptotically Distribution-Free } \\
\hline & \multirow{2}{*}{$\begin{array}{l}\text { Event } \\
\text { image }\end{array}$} & \multicolumn{2}{|c|}{ Brand equity } & \multicolumn{2}{|c|}{ Congruence } & \multirow{2}{*}{$\begin{array}{l}\text { FIFA's } \\
\text { reputation }\end{array}$} \\
\hline & & Coca-Cola & Adidas & Coca-Cola & Adidas & \\
\hline & $\mathrm{CR}=.842$ & $\mathrm{CR}=.954$ & $\mathrm{CR}=.928$ & $\mathrm{CR}=.926$ & $\mathrm{CR}=.906$ & $\mathrm{CR}=.925$ \\
\hline Event Image & $.473^{b}$ & .274 & .345 & .247 & .371 & .332 \\
\hline Coca-Cola Brand Equity & .075 & .840 & .400 & .558 & .303 & .259 \\
\hline Adidas Brand Equity & .119 & .160 & .764 & .328 & .525 & .264 \\
\hline Coca-Cola Congruence & .061 & .311 & .108 & .715 & .476 & .320 \\
\hline Adidas Congruence & .138 & .092 & .276 & .227 & .659 & .284 \\
\hline FIFA's Reputation & .110 & .067 & .070 & .102 & .081 & .806 \\
\hline
\end{tabular}

Note. Diagonal figures in bold denote the Average Variance Extracted; Figures below the diagonal denote the correlation square between the constructs; Figures above the diagonal denote the correlation between the constructs.

${ }^{\text {a }}$ Standardized Coefficient $<0.6 ;{ }^{\mathrm{b}}$ Average Variance Extracted $<0.5$.

The study hypotheses test was performed using Structural Equations Modeling (SEM) (see Figure 2). 


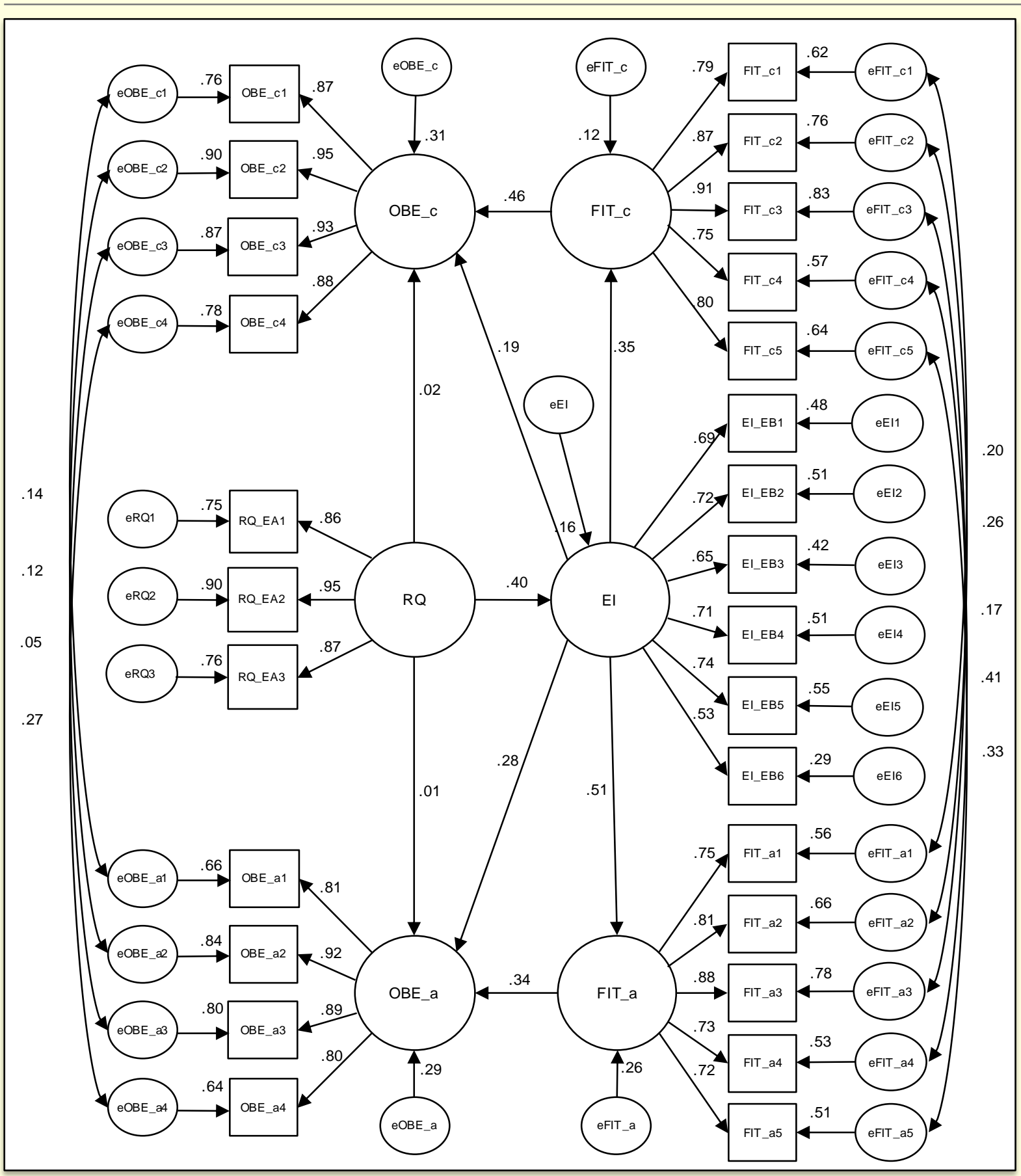

Figure 2. Structural model

The substantive hypotheses test was performed by analyzing the significance and the relevance of the paths between these constructs: Reputation, Event Image, and Sponsor's Brand Equity. In order to sustain the hypotheses, the standardized coefficients, the CR, and the p-value below 0.05 were examined (Hair, Black, Babin, \& Anderson, 2010).

The model was able to explain $16.1 \%$ of the variance of the Event Image, $31.0 \%$ of the variance of the Coca-Cola Brand Equity, and $29.3 \%$ of the Adidas Brand Equity. The paths analyzed 
between Reputation, Event Image, and Sponsor's Brand Equity latent variables were significant for the relationships between Reputation and Event Image, Event Image and Coca-Cola Brand Equity, and Event Image and Adidas Brand Equity. Thus, hypotheses H1, H3a, and H3b were supported.

Table 3

Results of hypotheses $\mathrm{H1}, \mathrm{H} 2$, and $\mathrm{H} 3$

\begin{tabular}{|c|c|c|c|c|c|}
\hline Hip. & Path & Valence & $\begin{array}{l}\text { Standardized } \\
\text { coefficient }\end{array}$ & C.R. & p-value \\
\hline $\mathrm{H}_{1}$ & Event image $\leftarrow$ FIFA's reputation & $(+)$ & 0.402 & 16.022 & *** \\
\hline $\mathrm{H}_{2 \mathrm{a}}$ & Coca Cola brand equity $\leftarrow$ FIFA's reputation & $(+)$ & 0.018 & 0.797 & 0.426 \\
\hline $\mathrm{H}_{2 b}$ & Adidas brand equity $\leftarrow$ FIFA's reputation & $(+)$ & 0.013 & 0.514 & 0.607 \\
\hline $\mathrm{H}_{3 \mathrm{a}}$ & Coca Cola brand equity $\leftarrow$ Event image & $(+)$ & 0.186 & 6.807 & *** \\
\hline \multirow[t]{4}{*}{$\mathrm{H}_{3 \mathrm{~b}}$} & Adidas brand equity $\leftarrow$ Event image & $(+)$ & 0.278 & 8.020 & *** \\
\hline & Event image & $0.161^{\mathrm{a}}$ & & & \\
\hline & Coca Cola brand equity & $0.310^{\mathrm{a}}$ & & & \\
\hline & Adidas brand equity & $0.293^{\mathrm{a}}$ & & & \\
\hline
\end{tabular}

Note. C.R. refers to Construct Reliability; ${ }^{* \star}$ Significant at $p<0.01 ;{ }^{a}\left(R^{2}\right)$ refers to explained variance of the latent variable

The Four Steps Approach (Baron \& Kenny, 1986) and the Sobel test (1982) were conducted to check the mediating effect of the Congruence latent variable (see Table 4).

Table 4

\section{Mediation test}

\begin{tabular}{|c|c|c|c|c|c|c|}
\hline Brand & Steps & Variables & $\begin{array}{l}\text { Unstandardized } \\
\text { coefficients }\end{array}$ & Standard error & P-value & Sobel test (z) \\
\hline \multirow{10}{*}{ Coca-Cola } & Step 1 & & & & & \multirow{10}{*}{8.324 *** } \\
\hline & Dependent & OBE & - & - & - & \\
\hline & Independent & El & 0.869 & 0.084 & $* * *$ & \\
\hline & Step 2 & & & & & \\
\hline & Dependent & FIT & - & - & - & \\
\hline & Independent & $\mathrm{El}$ & 0.686 & 0.073 & $* * *$ & \\
\hline & Steps 3 and 4 & & & & & \\
\hline & Dependent & OBE & - & - & - & \\
\hline & Mediator & FIT & 0.538 & 0.030 & $* * *$ & \\
\hline & Independent & El & 0.457 & 0.066 & *** & \\
\hline
\end{tabular}

Continues 
Table 4 (continued)

\begin{tabular}{|c|c|c|c|c|c|c|}
\hline Brand & Steps & Variables & $\begin{array}{l}\text { Unstandardized } \\
\text { coefficients }\end{array}$ & Standard error & P-value & Sobel test (z) \\
\hline \multirow{10}{*}{ Adidas } & Step 1 & & & & & \multirow{10}{*}{$7.839 * * *$} \\
\hline & Dependent & OBE & - & - & - & \\
\hline & Independent & El & 0.964 & 0.078 & $* * *$ & \\
\hline & Step 2 & & & & & \\
\hline & Dependent & FIT & - & - & - & \\
\hline & Independent & El & 0.819 & 0.068 & $* * *$ & \\
\hline & Steps 3 and 4 & & & & & \\
\hline & Dependent & OBE & - & - & - & \\
\hline & Mediator & FIT & 0.413 & 0.040 & $* * *$ & \\
\hline & Independent & $\mathrm{El}$ & 0.541 & 0.069 & $* * *$ & \\
\hline
\end{tabular}

Note. ${ }^{* * *}$ Significant at $\mathrm{p}<0.001$.

The results for Coca-Cola and Adidas were similar. The first step revealed that the direct relationship between the latent variable Event Image and the variables Coca-Cola Brand Equity and Adidas Brand Equity was significant. Step 2 showed that the direct relationship between the latent variable Event Image and the latent variables Congruence between the Mega-Event and Coca-Cola and Congruence between the Mega-Event and Adidas was significant. Finally, steps 3 and 4 supported that Congruence mediates the influence of the Event Image on the Brand Equity of both brands, pointing to a partial mediation. The Sobel test supported the significance of the indirect effect of the Event Image on the Sponsor's Brand Equity.

To validate the mediation results, we applied the bootstrap method with 2000 samples using the bias-corrected percentile method. Results support the partial mediation verified in a previous analysis (see Table 5).

Table 5

\section{Effects on the sponsor's brand equity}

\begin{tabular}{llll}
\hline Hypothesis & Direct $(\mathrm{p}$-value $)$ & Indirect $(\mathrm{p}$-value $)$ & Result \\
\hline $\mathrm{EI} \rightarrow \mathrm{FITc} \rightarrow$ OBEc & $0.186(0.003)$ & $0.159(0.017)$ & Partial mediation \\
$\mathrm{EI} \rightarrow \mathrm{FITa} \rightarrow$ OBEa & $0.278(0.001)$ & $0.172(0.021)$ & Partial mediation \\
\hline
\end{tabular}

Finally, the influence of FIFA's reputation was assessed so that the direct, indirect, and overall effects on the Sponsor's Brand Equity could be determined (see Table 6). According to what has been previously demonstrated, FIFA's reputation did not exert a direct significant effect (standardized coefficient $=0.018 ; \mathrm{p}$-value $=0.426$ ) on Coca-Cola Brand Equity. The indirect effect (standardized coefficient $=0.139$ ) was significant. The explained variance of Coca-Cola Equity $(31.0 \%)$ was the result of the direct effect of the perception of congruence between Coca-Cola 
and the FIFA World Cup (standardized coefficient $=0.459$; p-value $<0.01$ ), the direct effect of the Event Image (standardized coefficient $=0.186$ ), and the indirect effect of FIFA's Reputation (standardized coefficient $=0.139$ ).

In this analysis, it was possible to verify that FIFA's Reputation did not exert significant direct influence on Adidas Brand Equity (standardized coefficient $=0.013 ; \mathrm{p}$-value $=0.607$ ). The indirect effect (standardized coefficient $=0.181$ ) is significant. Adidas's brand equity explained variance was a consequence of the indirect effect of the perception of congruence between Adidas and the FIFA World Cup (standardized coefficient $=0.340$; p-value $<0.01$ ), the direct effect of the Event Image (standardized coefficient $=0.278$ ), the indirect effect of the Event Image (standardized coefficient $=0.172$ ), and the indirect effect of FIFA's reputation (standardized coefficient $=0.181$.

Table 6

\section{Effects on the sponsor's brand equity}

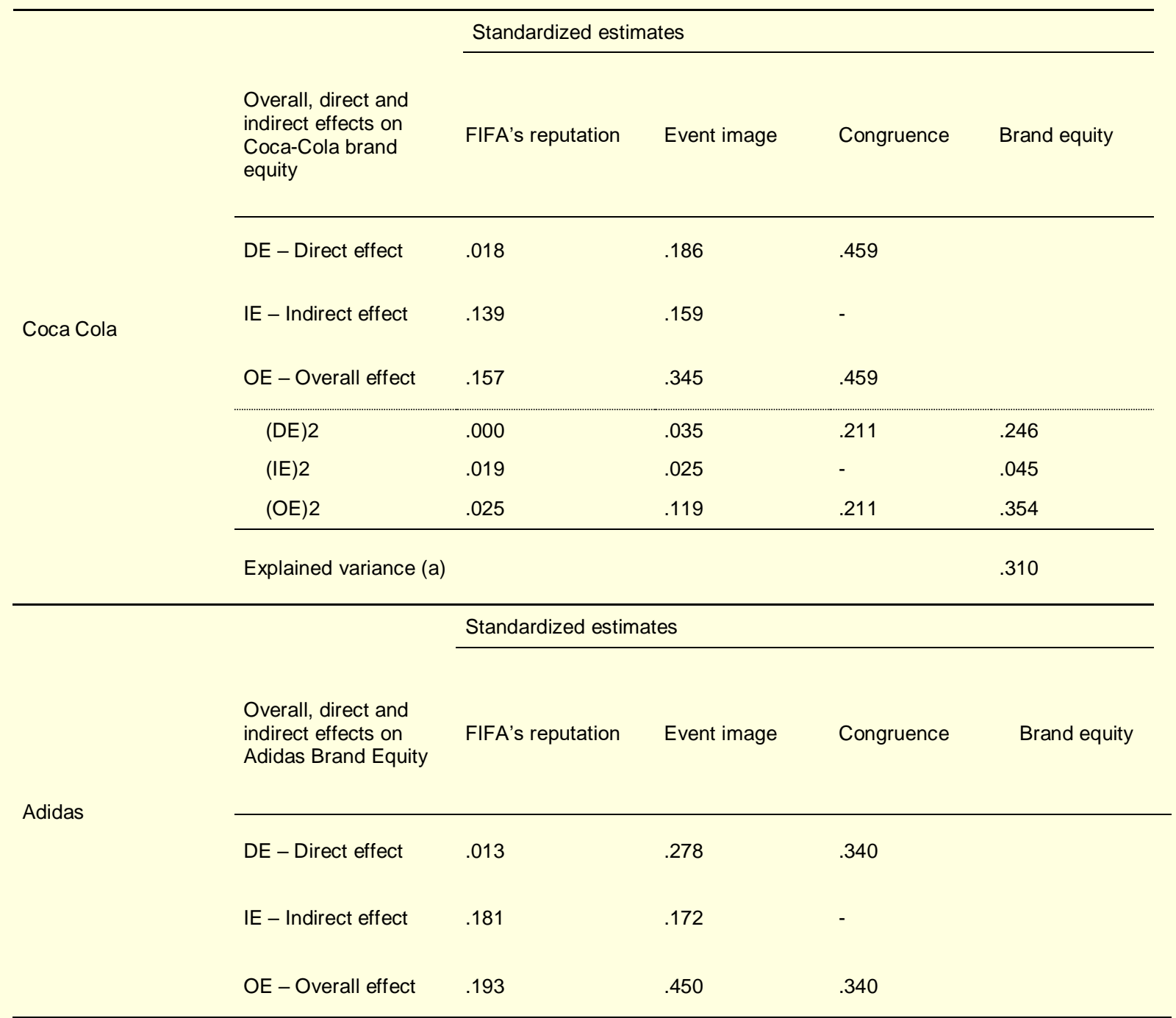

Continues 


\section{Table 6 (continued)}

\begin{tabular}{|c|c|c|c|c|c|}
\hline \multirow{6}{*}{ Adidas } & \multirow{3}{*}{$\begin{array}{l}\text { Overall, direct and } \\
\text { indirect effects on } \\
\text { Coca-Cola brand } \\
\text { equity } \\
\text { (DE)2 }\end{array}$} & \multicolumn{4}{|c|}{ Standardized estimates } \\
\hline & & FIFA's reputation & Event image & Congruence & Brand equity \\
\hline & & .000 & .077 & 116 & .193 \\
\hline & (IEI2 & .033 & .030 & - & .062 \\
\hline & (OE)2 & .037 & .203 & .116 & .355 \\
\hline & \multicolumn{4}{|c|}{ Explained variance (a) } & .293 \\
\hline
\end{tabular}

Note. (a) Squared Multiple Correlation I [ $\Sigma(E T) 2-\Sigma(E I) 2]$

\section{Discussion}

\section{The relationship between FIFA's reputation and World Cup image}

The results support that the sports mega-event organizer's reputation has a direct influence on the mega-event image, a result consonant with the study by M. Walker et al. (2013) conducted in South Africa. The study relates perceptions of FIFA with World Cup image, suggesting that FIFA's perception as a socially responsible organization influences the mega-event image.

Given that the reputation is comprised of a set of associations (Clardy, 2012; T. J. Brown, Dacin, Pratt, \& Whetten, 2006), the primary associations referring to FIFA's corporate reputation may be transferred to its main product. Associations with the World Cup become secondary and they influence its image, as pointed out by several different studies about sponsorship (Cornwell, Weeks, \& Roy, 2005; Grohs et al., 2004; Grohs \& Reisinger, 2014; K. Gwinner, 1997; K. P. Gwinner, Larson, \& Swanson, 2009); however, this relationship between the mega-event proprietary organizer and the mega-event image is practically unexplored in empirical studies. For this reason, the current study finding represents an advancement in this field of knowledge. The World Cup holds a strong and positive image in the mega-event live spectators' minds and association with this event may bring benefits to sponsors. The mega-event image, whether stable or not, is being affected by FIFA's reputation and it may be enhanced or damaged depending on expectations being surpassed or unmet, respectively.

\section{The relationship between FIFA's reputation and sponsor brand equity}

The results indicate that the direct and indirect impacts of FIFA's reputation on sponsor brand equity show little practical relevance, and the indirect impact is the only one with statistical significance (2\% for Coca-Cola and 3\% for Adidas), therefore critiques related to FIFA do not negatively influence the perception about the sponsoring brands. 
Even if the connection between brand equity, corporate credibility, and reputation is not yet clear for certain academic sectors (Chun, 2005), an empirical study conducted in Brazil already supported the influence of a brand's reputation on brand equity (Torres, Gonçalves, Gosling, \& Veiga, 2011). Nevertheless, the focus of this study is a situation with a different configuration: the relationship between the reputation of an organization (FIFA) and the brand equity of other corporations (Coca-Cola and Adidas).

Brand equity can be built through marketing efforts or through direct and indirect sources of information (Raggio \& Leone, 2007). It has been postulated that the development of brand equity occurs over time (Aaker, 1998; Dolphin, 2003), and corporations such as the ones investigated in this study invest in brand development strategies (Adidas, 2005; The Coca-Cola Company, n.d.). Consequently, it may be assumed that the two sponsors have established consumer-based brand equities that protect them from certain adverse influences.

Nonetheless, sponsors are often cited in literature as one of the few stakeholder groups capable of exerting influence over FIFA to seek a true reform against corruption (Onwumechili \& Bedeau, 2017; Pielke, 2013). If FIFA's reputation continues to deteriorate, sponsors might be pressured to force some concessions.

\section{The relationship between the sports mega-event image and sponsor brand equity}

The influence of the sport property image on the sponsor's brand equity and on other related variables indicates that the sponsorship might bring a competitive advantage, promoting differentiation and adding value to the brand (Amis, Pant, \& Slack, 1997; Cliffea \& Motion, 2005; Dolphin, 2003). We could not find empirical studies relating mega-event image with sponsor brand equity. Some studies investigated the direct influence event image has on sponsor image (Grohs \& Reisinger, 2014; Grohs et al., 2004; Nadeau et al., 2013). Nadeau, O'Reilly and Heslop (2013) and Grohs, Wagner and Vsetecka (2004) supported the existence of direct influence of the Beijing 2008 Olympic Games image and the Ski Alpino World Championship on sponsor image without an influence from the perception of congruence between the event and the sponsor. Grohs and Reisinger (2014) and also Grohs (2016) concluded that there is a direct effect of an event's brand image and the perception of fit on sponsor image. They modeled these constructs as independent variables, supporting the significance of these relationships, but without considering an interaction between them. The influence of congruence on the sponsor image was higher than the influence of the event image.

A strong correlation between event image and brand equity was noticed. When congruence is modeled as a mediator between these constructs, the direct influence of the event image diminishes. This demonstrates the mediating role of congruence. 


\section{The influence of congruence}

The perception of congruence between the World Cup and the sponsors appears as the most prominent influence on brand equity. The results suggest that congruence exerts a mediating effect on the relationship between event image and brand equity. Since the brand had a direct effect on the value perceived by the respondents, the mediation is partial, a result that is similar to previous studies and brings evidence of the influence perception of congruence between sponsor and property has on sponsorship strategy success. The perception of congruence between the sponsor and sponsored property might influence the image and the sponsor's brand recognition (Grohs et al., 2004; G.-Y. Koo et al., 2006; K. P. Gwinner et al., 2009), the attitudes towards a sponsor (Biscaia \& Rocha, 2018; K. Gwinner \& Bennett, 2008; Shin et al., 2018; Speed \& Thompson, 2000), the sponsor's credibility (J. Koo \& Lee, 2018; Wang, 2017), the brand's attractiveness (Woisetschläger, Eiting, Haselhoff, \& Michaelis, 2010), and purchase intention (Close \& Lacey, 2013). The perception of fit may be even more relevant in spectator response in the context of mega-events due to the higher level of expectations when compared to smaller nonprofit events (Ko et al., 2017).

The study supports K. P. Gwinner and Eaton's (1999) thesis that the congruence between sponsor and property may be perceived according to functionality and symbolic alignment of the images. The perception of congruence between Adidas and the World Cup is based on functionality since the corporation is the event's sports material supplier, responsible for developing a range of products ranging from the tournament ball to the referees' uniforms. The perception of congruence between Coca-Cola and the World Cup is based on the symbolic alignment of their images, which is explained by Associative Network Theory (Collins \& Loftus, 1975) and Schema Theory (Axelrod, 1973). People perceive this congruence based on the longevity of the partnership, because they associate Coca-Cola with moments of entertainment or due to other reasons that enable the connection between the constructs in a network of associated information. If we assume, for instance, that (a) the action of drinking Coca-Cola and (b) watching a World Cup match are associated with a moment of entertainment, the associative network knots of Coca-Cola and the World Cup are connected. Consistent sponsorship activation through marketing communication is likely to have reinforced such a connection (Biscaia \& Rocha, 2018; Weeks et al., 2018).

\section{Limitations and suggestions for future studies}

The study presents limitations related to the methodology applied. The model does not contemplate all the variables that may influence sponsor's brand equity in the context of sports mega-events. The results cannot be generalized to contexts where there is asymmetry between the sponsor's and the mega-event brand power. The analyses showed psychometric fragilities in the scale used to measure reputation and event image. There are also limitations related to sampling and data collection since the interviews were assisted, which may result in an interviewer bias. Lastly, another limitation concerns the fact that the dependent and independent variables were 
supplied by the same respondents, so common method bias may have influenced some of the results, though EFA did not present evidence of the occurrence of such an effect.

Future studies could test the conceptual model on other sports mega-events or on small-scale events where organizer reputation might represent a threat to the event and sponsor image. Future studies may investigate the existence of a mediating effect of variables such as gender, country of residence, and age range on the hypothesized relationships. Taking into account the perception of congruence between the sponsor and the property, the suggestion is that future studies advance the development of a scale to measure mega-event image.

\section{Contributions}

1st author - Concept and design of the research, literature review, data collection, analysis and discussion of results, writing and analysis of the manuscript, final revision of the manuscript for submission.

2nd author - Concept, design of the research, analysis and discussion of results, analysis of the manuscript.

3rd author - Discussion of results, writing and analysis of the manuscript, final revision of the manuscript for submission.

\section{References}

Aaker, D. A. (1998). Marcas - brand equity: Gerenciando o valor da marca. São Paulo, Brazil: Elsevier.

Adidas. (n.d.). Corporate. Retrieved April 8, 2019, from https://www.adidas.co.za/help-topics-corporate.html

Adidas. (2005). FIFA World Cup sponsor in 2010 and 2014. Retrieved April 8, 2019, from https://www.adidasgroup.com/en/media/news-archive/press-releases/2005/adidas-fifa-world-cup-sponsor-2010-and-2014/

Amis, J., Pant, N., \& Slack, T. (1997). Achieving a sustainable competitive advantage: A resource-based view of sport sponsorship. Journal of Sport Management, 11(1), 80-96. https://doi.org/10.1123/jsm.11.1.80

Amorim, J. G. B. de, \& Almeida, V. M. C. de. (2015). The effect of simultaneous sponsorship of rival football teams. BAR - Brazilian Administration Review, 12(1), 63-87. https://doi.org/10.1590/1807-7692bar2015140059

Axelrod, R. (1973). Schema theory: An information processing model of perception and cognition. The American Political Science Review, 67(4), 1248-1266. https://doi.org/10.2307/1956546

Balmer, J. M. T. (2011). Corporate marketing myopia and the inexorable rise of a corporate marketing logic: Perspectives from identity-based views of the firm. European Journal of Marketing, 45(9/10), 1329-1352. https://doi.org/10.1108/03090561111151781

Balmer, J. M. T., \& Greyser, S. A. (2006). Corporate marketing: Integrating corporate identity, corporate branding, corporate communications, corporate image and corporate reputation. European Journal of Marketing, 40(7/8), 730-741. https://doi.org/10.1108/03090560610669964.

Baron, R. M., \& Kenny, D. A. (1986). The moderator-mediator variable distinction in social psychological research: Conceptual, strategic, and statistical considerations. Journal of Personality and Social Psychology, 51(6), 1173-1182. https://doi.org/10.1037//0022-3514.51.6.1173

Becker, K., Kautsky, R., \& Widholm, A. (2014). Watching football in the fan park: Mediatization, spectatorship and fan identity. In L. Duits, K. Zwaan, \& S. Reijnders (Eds.), The Ashgate research companion to fan cultures (pp. 275 288). Burlington, NJ: Ashgate. 
Biscaia, R., \& Rocha, C. (2018). Sponsorship of the 2016 Rio olympic games: An empirical examination of the reactions to local sponsors and rival brands. Sport Marketing Quarterly, 27(3), 180-196.

Brown, T. A. (2003). Confirmatory factor analysis of the Penn State Worry Questionnaire: Multiple factors or method effects?. Behaviour Research and Therapy, 41(12), 1411-1426. https://doi.org/10.1016/S00057967(03)00059-7

Brown, T. J., Dacin, P. A., Pratt, M. G., \& Whetten, D. A. (2006). Identity, intended image, constructed image and reputation: An interdisciplinary framework and suggested terminology. Journal of the Academy of Marketing Science, 34, 99-106. https://doi.org/10.1177/0092070305284969

Buil, I., Chernatony, L. d., \& Martínez, E. (2008). A cross-national validation of the consumer-based brand equity scale. Journal of Product EO Brand Management, pp. 384-392.

Buil, I., Martínez, E., \& Chernatony, L. d. (2013). The influence of brand equity on consumer responses. Journal of Consumer Marketing, 30(1), 62-74. https://doi.org/10.1108/07363761311290849

Byrne, B. M., Shavelson, R. J., \& Muthén, B. (1989). Testing for the equivalence of factor covariance and mean structures: The issue of partial measurement invariance. Psychological Bulletin, 105(3), 456-466. http://dx.doi.org/10.1037/0033-2909.105.3.456

Carpes, G. (2014, July 15). Copa trouxe ao Rio 886 mil turistas e movimentou R\$ 4,4 bilhões. Retrieved July 1, 2015, from http://copa2014.gov.br/pt-br/noticia/copa-trouxe-ao-rio-886-mil-turistas-e-movimentou-de-r-44-bilhoes

Chadwick, S., \& Burton, N. (2011). The evolving sophistication of ambush marketing: A typology of strategies. Thunderbird International Business Review, 53(6), 709-719. https://doi.org/10.1002/tie.20447

Christodoulides, G., \& de Chernatony, L. (2010). Consumer-based brand equity conceptualisation and measurement - A literature review. International Journal of Market Research, 52(1), 43-66. https://doi.org/10.2501/s1470785310201053

Chun, R. (2005). Corporate reputation: Meaning and measurement. International Journal of Management Reviews, 7(2), 91-109. https://doi.org/10.1111/j.1468-2370.2005.00109.x

Clardy, A. (2012). Organizational reputation: Issues in conceptualization and measurement. Corporate Reputation Review, 15(4), 285-303. https://doi.org/10.1057/crr.2012.17

Cliffea, S. J., \& Motion, J. (2005). Building contemporary brands: A sponsorship-based strategy. Journal of Business Research, 58(8), 1068-1077. https://doi.org/10.1016/j.jbusres.2004.03.004

Close, A. G., \& Lacey, R. (2013). Fit matters? Asymmetrical impact for effectiveness on sponsors and event marketers. Sport Marketing Quarterly, 22(2), 71-82.

Cole, D. A., Ciesla, J. A., \& Steiger, J. H. (2007). The insidious effects of failing to include design-driven correlated residuals in latent-variable covariance structure analysis. Psychological Methods, 12(4), 381-398. https://doi.org/10.1037/1082-989x.12.4.381

Collins, A. M., \& Loftus, E. F. (1975). A spreading activation theory of semantic processing. Psychological Review, 82(6), 407-428. https://doi.org/10.1037//0033-295x.82.6.407

Cornwell, T. B. (2008). State of the art and science in sponsorship-linked marketing. Journal of Advertising, $37(3), 41$ 55. https://doi.org/10.2753/joa0091-3367370304

Cornwell, T. B., \& Maignan, I. (1998). An international review of sport sponsorship. Journal of Advertising, $27(1), 1$ 21. https://doi.org/10.1080/00913367.1998.10673539

Cornwell, T. B., Weeks, C. S., \& Roy, D. P. (2005). Sponsorship-linked marketing: Opening the black box. Journal of Advertising, 34(2), 21-42. https://doi.org/10.1080/00913367.2005.10639194

Deitz, G. D., Myers, S. W., \& Stafford, M. R. (2012). Understanding consumer response to sponsorship information: A resource-matching approach. Psychology and Marketing, 29(4), 226-239. https://doi.org/10.1002/mar.20517

Dolphin, R. R. (2003). Sponsorship: Perspectives on its strategic role. Corporate Communications, 8(3), 173-186. https://doi.org/10.1108/13563280310487630

Drengner, J., Jahn, S., \& Zanger, C. (2011). Measuring event-brand congruence. Event Management, 15(1), 25-36. https://doi.org/10.3727/152599511x12990855575060 
Farrelly, F., Quester, P., \& Burton, R. (2006). Changes in sponsorship value: Competencies and capabilities of successful sponsorship relations. Industrial Marketing Management, 35(8), 1016-1026. https://doi.org/10.1016/j.indmarman.2006.05.006

Fédération Internationale de Football Association. (2015, May 28-29). FIFA Financial Report 2014. Retrieved from http://www.fifa.com/mm/document/affederation/administration/02/56/80/39/fr2014weben_neutral.pdf

Fédération Internationale de Football Association. (n.d.a). FIFA Fan Fest ${ }^{\mathrm{TM}}$ goes global for the first time. Retrieved July 1, 2015, from http://www.fifa.com/worldcup/news/y=2009/m=11/news=fifa-fan-festtm-goes-global-for-the-firsttime-1137509.html

Fédération Internationale de Football Association. (n.d.c). FIFA Partners - Coca-Cola. Retrieved July 1, 2015, from http://www.fifa.com/about-fifa/marketing/sponsorship/partners/coca-cola.html

Fédération Internationale de Football Association. (n.d.b). 2014 FIFA World Cup Brazil - Marketing Highlights. Retrieved July 1, 2015, from http://www.fifa.com/marketinghighlights/brazil2014/index.htm

Fleck, N. D., \& Quester, P. (2007). Birds of a feather flock together... definition, role and measure of congruence: An application to sponsorship. Psychology $\mathcal{E}$ Marketing, 24(11), 975-1000. https://doi.org/10.1002/mar.20192

Floyd, F. J., \& Widaman, K. F. (1995). Factor analysis in the development and refinement of clinical assessment instruments. Psychological Assessment, 7(3), 286-299. http://doi.org/10.1037/1040-3590.7.3.286

Fombrun, C. J., Gardberg, N. A., \& Sever, J. M. (2000). The reputation quotient: A multi-stakeholder measure of corporate reputation. Journal of Brand Management, 7(4), 241-255. https://doi.org/10.1057/bm.2000.10

Fonseca, P. (2013, June 21). Imaginava-se tudo na Copa, menos os protestos. Retrieved July 24, 2014, from http://br.reuters.com/article/sportsNews/idBRSPE95K06B20130621

Fornell, C., \& Larcker, D. F. (1981). Evaluating structural equation models with unobservable variables and measurement error. Journal of Marketing Research, 18(1), 39-50. https://doi.org/10.2307/3151312

Grohs, R. (2016). Drivers of brand image improvement in sports-event sponsorship. International Journal of Advertising, 35(3), 391-420. https://doi.org/10.1080/02650487.2015.1083070

Grohs, R., \& Reisinger, H. (2014). Sponsorship effects on brand image: The role of exposure and activity involvement. Journal of Business Research, 67(5), 1018-1025. https://doi.org/10.1016/j.jbusres.2013.08.008

Grohs, R., Wagner, U., \& Vsetecka, S. (2004). Assessing the effectiveness of sport sponsorships - An empirical examination. Schmalenbach Business Review, 56(2), 119-138. https://doi.org/10.1007/bf03396689

Gwinner, K. (1997). A model of image creation and image transfer in event sponsorship. International Marketing Review, 14(3), 145-158. https://doi.org/10.1108/02651339710170221

Gwinner, K., \& Bennett, G. (2008). The impact of brand cohesiveness and sport identification on brand fit in a sponsorship context. Journal of Sport Management, 22(4), 410-426. https://doi.org/10.1123/jsm.22.4.410

Gwinner, K. P., \& Eaton, J. (1999). Building brand image through event sponsorship: The role of image transfer. Journal of Advertising, 28(4), 47-57. https://doi.org/10.1080/00913367.1999.10673595

Gwinner, K. P., Larson, B. V., \& Swanson, S. R. (2009). Image transfer in corporate event sponsorship: Assessing the impact of team identification and event-sponsor fit. International Journal of Management and Marketing Research, 2(1), 1-15.

Hair, J. F., Black, W. C., Babin, B. J., \& Anderson, R. E. (2010). Multivariate data analysis (7th ed.). Upper Saddle River, NJ: Prentice Hall.

Heslop, L. A., Nadeau, J., O'Reilly, N., \& Armenakyan, A. (2013). Mega-event and country co-branding: image shifts, transfers and reputational impacts. Corporate Reputation Review, 16(1), 7-33. https://doi.org/10.1057/crr.2012.23

Horne, J. (2015). Assessing the sociology of sport: On sports mega-events and capitalist modernity. International Review for the Sociology of Sports, 50(4-5), 466-471. https://doi.org/10.1177/1012690214538861

Horne, J., \& Manzenreiter, W. (2006). An introduction to the sociology of sports mega-events. In J. Horne, \& W. Manzenreiter (Eds.), Sports mega-events: Social scientific analyses of a global phenomenon (pp. 1-24). Oxford, UK: WileyBlackwell. 
IEG Sponsorship Report. (2008, April 7). Setting the standard: Coca-Cola's new approach to sponsorship. Retrieved July 1, 2015, from http://www.sponsorship.com/iegsr/2008/04/07/Setting-The-Standard-Coca-Cola-s-NewApproach-To-.aspx

International Olympic Committee. (2013, September 9). Building a legacy through sport - IOC final report 2009-2012. Retrieved February 25 , 2015 ,

from http://www.olympic.org/Documents/IOC_Interim_and_Final_Reports/IOC_Final_Report_2009. 2012_ENG.pdf

Jago, L., Dwyer, L., Lipman, G., Lill, D. van, \& Vorster, S. (2010). Optimising the potential of mega-events: An overview. International Journal of Event and Festival Management, 1(3), 220-237. https://doi.org/10.1108/17852951011078023

Kaplanidou, K., Karadakis, K., Gibson, H., Thapa, B., Walker, M., Geldenhuys, S., \& Coetzee, W. (2013). Quality of life, event impacts, and mega-event support among South African residents before and after the 2010 FIFA World Cup. Journal of Travel Research, 52(5), 631-645. https://doi.org/10.1177/0047287513478501

Kaplanidou, K., \& Vogt, C. (2006). Do sport tourism events have a brand image? In Proceedings of the 2006 Northeastern Recreation Research Symposium (General Technical Report NRS-P-14, pp. 2-7). New York, NY: U.S. Forest Service, Northern Research Station.

Keller, K. L. (1993). Conceptualizing, measuring, and managing customer-based brand equity. Journal of Marketing, 57(1), 1-22. https://doi.org/10.1177/002224299305700101

Kesenne, S. (2012). The economic impact, costs and benefits of the FIFA World Cup and the Olympic Games: who wins, who loses? In W. Maennig \& A. Zimbalist (Eds.), International handbook on the economics of mega sporting events (pp. 270-278). Cheltenham, UK: Edward Elgar Publishing.

Ko, Y. J., Chang, Y., Park, C., \& Herbst, F. (2017). Determinants of consumer attitude toward corporate sponsors: A comparison between a profit and nonprofit sport event sponsorship. Journal of Consumer Behaviour, 16(2), 176186. https://doi.org/10.1002/cb.1622

Koo, G.-Y., Quarterman, J., \& Flynn, L. (2006). Effect of perceived sport event and sponsor image fit on consumer's cognition, affect, and behavioral intentions. Sport Marketing Quarterly, 15(2), 80-90. Retrieved from http://fitpublishing.com/content/effect-perceived-sport-event-and-sponsor-image-fit-consumerscognition-affectand-behavioral

Koo, J., \& Lee, Y. (2018). Sponsor-event congruence effects: The moderating role of sport involvement and mediating role of sponsor attitudes. Sport Management Review, 22(2), 222-234. https://doi.org/10.1016/j.smr.2018.03.001

Lenskyj, H. J. (2000). Inside the Olympic industry: Power, politics, and activism. New York, NY: SUNY Press.

Lenskyj, H. J. (2015). Sport mega-events and leisure studies. Leisure Studies, 34(4), 501-507. https://doi.org/10.1080/02614367.2014.986509

Madrigal, R., Bee, C., \& LaBarge, M. (2005). Using the Olympics and FIFA World Cup to enhance global brand equity: A case study of two companies in the payment services category. In: J. A. Cornwell \& T. B. Cornwell (Eds.), Global sport sponsorship (pp. 179-190). Oxford, UK: Berg.

Meenaghan, J. A. (1983). Commercial sponsorship. European Journal of Marketing, 17(7), 5-73. https://doi.org/10.1108/EUM0000000004825.

Meenaghan, T. (1991). The role of sponsorship in the marketing communications mix. International Journal of Advertising, 10(1), 35-47. https://doi.org/10.1080/02650487.1991.11104432

Moreno, A. C. (2013, June 28). Resultados das manifestações de junho. Retrieved July 24, 2014, from http://g1.globo.com/brasil/linha-tempo-manifestacoes-2013/platb/

Müller, M. (2015). What makes an event a mega-event? Definitions and sizes. Leisure Studies, 34(6), 627-642. https://doi.org/10.1080/02614367.2014.993333

Nadeau, J., O'Reilly, N., \& Heslop, L. (2011). China's Olympic destination: Tourist evaluations of China and the games. International Journal of Culture, Tourism and Hospitality Research, 5(3), 235-246. https://doi.org/10.1108/17506181111156934 
Nadeau, J., O'Reilly, N., \& Heslop, L. (2013). Linking place, mega-event and sponsorship evaluations. Journal of Product $\mathcal{E}$ Brand Management, 22(2), 129-141. https://doi.org/10.1108/10610421311321004

Nufer, G., \& Bühler, A. (2010). How effective is the sponsorship of global sports events? A comparison of the FIFA World Cups in 2006 and 1998. International Journal of Sports Marketing and Sponsorship, 11(4), 303-319. https://doi.org/10.1108/ijsms-11-04-2010-b004

Oliveira, M. O., \& Luce, F. B. (2012). Reflections about brand equity, brand value and their consequences. Proceedings of Encontro de Marketing da Anpad, Curitiba, PR, Brazil, 5.

Olson, E. L. (2011). Does sponsorship work in the same way in different sponsorship contexts? European Joumal of Marketing, 44(1/2), 180-199. https://doi.org/10.1108/03090561011008664

Onwumechili, C., \& Bedeau, K. (2017). Analysis of FIFA's attempt at image repair. Communication $\mathcal{E}$ Sport, 5(4), 407-427. https://doi.org/10.1177/2167479516633843

Pappu, R., \& Cornwell, T. B. (2014). Corporate sponsorship as an image platform: Understanding the roles of relationship fit and sponsor-sponsee similarity. Journal of the Academy of Marketing Science, 42(5), 490-510. https://doi.org/10.1007/s11747-014-0373-x

Pappu, R., Quester, P. G., \& Cooksey, R. W. (2005). Consumer-based brand equity: Improving the measurement empirical evidence. Journal of Product $\mathcal{E}$ Brand Management, 14(3), 143-154. https://doi.org/10.1108/10610420510601012

Pielke, R., Jr. (2013). How can FIFA be held accountable? Sport Management Review, 16(3), 255-267. https://doi.org/10.1016/j.smr.2012.12.007

Raggio, R. D., \& Leone, R. P. (2007). The theoretical separation of brand equity and brand value: Managerial implications for strategic planning. Journal of Brand Management, 14(5), 380-395. https://doi.org/10.1057/palgrave.bm.2550078

Rifon, N. J., Choi, S. M., Trimble, C. S., \& Li, H. (2004). Congruence effects in sponsorship - The mediating role of sponsor credibility and consumer attributions of sponsor motive. Journal of Advertising, 33(1), 29-42. https://doi.org/10.1080/00913367.2004.10639151

Roberts, K. (2004). The leisure industries. London, UK: Palgrave Macmillan.

Roche, M. (2000). Mega-events and modernity: Olympics and expos in the growth of global culture. London, UK: Routledge.

Shin, H., Lee, H., \& Perdue, R. R. (2018). The congruity effects of commercial brand sponsorship in a regional event. Tourism Management, 67, 168-179. https://doi.org/10.1016/j.tourman.2018.01.016

Singer, J. E. (1968). Consistency as a stimulus process mechanism. In R. P. Abelson, E. Aronson, W. McGuire, T. Newcomb, M. Rosenberg, \& P. Tannenbaum (Eds.), Theories of cognitive consistency: A sourcebook (pp. 337-372). Chicago, IL: Randy McNally.

Sjovall, A. M., \& Talk, A. C. (2004). From actions to impressions: Cognitive attribution theory and the formation of corporate reputation. Corporate Reputation Review, 7(3), 269-281. https://doi.org/10.1057/palgrave.crr.1540225

Sobel, M. E. (1982). Asymptotic confidence intervals for indirect effects in structural equation models. Sociological Methodology, 13, 290-312. https://doi.org/10.2307/270723

Speed, R., \& Thompson, P. (2000). Determinants of sports sponsorship response. Joumal of the Academy of Marketing Science, 28(2), 226-238. https://doi.org/10.1177/0092070300282004

The Coca-Cola Company. (n.d.). Contact us - FAQs. Retrieved July 1, 2015, from http://www.cocacolacompany.com/contact-us/faqs

Torres, D. F., Gonçalves, C. A., Gosling, M., \& Veiga, R. T. (2011). Modelo de avaliação da relação entre a reputação e o valor da marca: Um estudo no setor automotivo. Revista Eletrônica de Gestão Organizacional, 9(1), 57-85. Retrieved from https://periodicos.ufpe.br/revistas/gestaoorg/article/view/21711/18354

Walker, K. (2010). A systematic review of the corporate reputation literature: Definition, measurement, and theory. Corporate Reputation Review, 2(4), 357-387. https://doi.org/10.1057/crr.2009.26 
Walker, M., Hall, T., Todd, S. Y., \& Kent, A. (2011). Does your sponsor affect my perception of the event? The role of event sponsors as signals. Sport Marketing Quarterly, 20(3), 138-147

Walker, M., Kaplanidou, K., Gibson, H., Thapa, B., Geldenhuys, S., \& Coetzee, W. (2013). "Win in Africa, with Africa": Social responsibility, event image, and destination benefits. The case of the 2010 FIFA World Cup in South Africa. Tourism Management, 34, 80-90. https://doi.org/10.1016/j.tourman.2012.03.015

Walliser, B. (2003). An international review of sponsorship research: Extension and update. International Journal of Advertising, 22(1), 5-40. https://doi.org/10.1080/02650487.2003.11072838

Wang, M. C.-H. (2017). Investigating the different congruence effects on sports sponsor brand equity. International Journal of Sports Marketing and Sponsorship, 18(2), 196-211. https://doi.org/10.1108/ijsms-05-2017-089

Weeks, C. S., Humphreys, M. S., \& Cornwell, T. B. (2018). Why consumers misattribute sponsorships to nonsponsor brands: Differential roles of item and relational communications. Journal of Experimental Psychology, 24(2), 125-144. https://doi.org/10.1037/xap0000159

Weszka, P. (2011). FIFA world cup brand elements and local inspirations. Sport Marketing Quarterly, 20(3), 174-184. Retrieved from http://fitpublishing.com/content/fifa-world-cup-brand-elements-and-local-inspirations-p-174184

Woisetschläger, D. M., Eiting, A., Haselhoff, V. J., \& Michaelis, M. (2010). Determinants and consequences of sponsorship fit: A study of fan perceptions. Journal of Sponsorship, 3(2), 169-180.

Woisetschläger, D. M., \& Michaelis, M. (2012). Sponsorship congruence and brand image - A pre-post event analysis. European Journal of Marketing, 46(3/4), 509-523. https://doi.org/10.1108/03090561211202585

Yoo, B., \& Donthu, N. (2001). Developing and validating a multidimensional consumer-based brand equity scale. Journal of Business Research, 52(1), 1-14. https://doi.org/10.1016/s0148-2963(99)00098-3

Zheng, B., Liu, H., \& Davison, R. M. (2018). Exploring the relationship between corporate reputation and the public's crisis communication on social media. Public Relations Review, 44(1), 56-64. https://doi.org/10.1016/j.pubrev.2017.12.006

\section{Authors}

\section{Mariana Guará Rocha Coelho}

Universidade Federal do Rio de Janeiro, Instituto COPPEAD de Administração, Centro de Estudos em Marketing Esportivo

Rua Pascoal Lemme, 355, 21941-918, Rio de Janeiro, RJ, Brazil

mariana_coelho@msn.com

(iD) http://orcid.org/0000-0003-2147-3299

\section{João Guilherme Barbosa de Amorim}

Universidade Federal do Rio de Janeiro, Instituto COPPEAD de Administração

Rua Pascoal Lemme, 355, 21941-918, Rio de Janeiro, RJ, Brazil

jgbamorim@yahoo.com.br

(iD) https://orcid.org/0000-0002-9270-2901

\section{Victor Manoel Cunha de Almeida}

Universidade Federal do Rio de Janeiro, Instituto COPPEAD de Administração

Rua Pascoal Lemme, 355, 21941-918, Rio de Janeiro, RJ, Brazil

valmeida@coppead.ufrj.br

iD http://orcid.org/0000-0002-4433-0787 


\section{APPENDIX}

\section{Scale items phrasing in Portuguese, Spanish and English}

\begin{tabular}{|c|c|c|c|}
\hline Scales & Final phrasing after pre-test in Portuguese & Final phrasing after pre-test in Spanish & Final phrasing after pre-test in English \\
\hline \multirow{14}{*}{ El scale } & Lembranças. & Recuerdos. & Memories. \\
\hline & Originalidade da experiência. & Originalidad de la experiencia. & Originality of experience. \\
\hline & Culturalmente interessante. & Culturalmente interesante. & Culturally interesting. \\
\hline & Instalações atrativas. & Atractivo de las instalaciones. & Attractive facilities. \\
\hline & Variedade de atividades. & Variedad de actividades. & Variety of activities. \\
\hline & Entretenimento/vida noturna. & Entretenimiento/vida nocturna. & Entertainment/nightlife. \\
\hline & Facilidade de encontrar algo de interesse. & Facilidad para encontrar actividades de interés. & Ease of finding something of interest. \\
\hline & Qualidade do serviço. & Calidad de servicio. & Quality of service. \\
\hline & Facilidade de locomoção. & Facilidad de transporte y movimiento. & Ease of getting around. \\
\hline & Facilidade de estar presente. & Facilidad de asistencia. & Ease of attending. \\
\hline & Segurança. & Seguridad. & Safety. \\
\hline & Para toda a família. & Carácter familiar del evento. & Family friendly. \\
\hline & Pacífico. & Pacífico. & Peaceful. \\
\hline & Satisfação geral. & Satisfacción general. & Overall satisfaction. \\
\hline \multirow{3}{*}{ FIT scale } & Há uma ligação lógica entre Copa do Mundo e (MARCA). & $\begin{array}{l}\text { Hay una conexión lógica entre la Copa del Mundo y } \\
\text { (MARCA). }\end{array}$ & $\begin{array}{l}\text { There is a logical connection between the World Cup and } \\
\text { (BRAND). }\end{array}$ \\
\hline & $\begin{array}{l}\text { A imagem da Copa do Mundo e a imagem da (MARCA) } \\
\text { são compatíveis. }\end{array}$ & $\begin{array}{l}\text { La imagen de la Copa del Mundo y la imagen de } \\
\text { (MARCA) son similares. }\end{array}$ & $\begin{array}{l}\text { The image of the World Cup and the image of (BRAND) } \\
\text { are similar. }\end{array}$ \\
\hline & A Copa do Mundo e a (MARCA) combinam bem juntas. & (MARCA) combina bien con la Copa del Mundo. & (BRAND) and the World Cup fit together well. \\
\hline
\end{tabular}


A Copa do Mundo e a (MARCA) defendem os mesmos ideais.

FIT Scale do Mundo. Vale a pena comprar (MARCA). mesmo quando o produto é igual ao das outras marcas.

Mesmo que outras marcas tenham as mesmas características. eu prefiro comprar (MARCA).

OBE scale

Mesmo que haja outra marca tão boa quanto (MARCA). eu ainda prefiro comprar (MARCA).

Se outra marca não apresenta nenhuma diferença. parece Si otra marca no es diferente de (MARCA) en cualquier mais inteligente comprar (MARCA).

$\mathrm{RQ}$ Scale

A FIFA desperta sentimentos positivos.

A FIFA é merecedora de admiração e respeito.

A FIFA é digna de confiança.

A FIFA tem excelente liderança.

A FIFA tem uma visão clara para o futuro.

A FIFA reconhece e aproveita as oportunidades de mercado.

A FIFA é bem administrada.

\section{La FIFA despierta sentimientos positivos.}

La FIFA merece admiración y respeto.

La FIFA es digna de confianza.

La FIFA tiene un excelente liderazgo.

La FIFA tiene una visión clara de su futuro.

La FIFA reconoce y toma ventajas de las oportunidades del mercado.

La FIFA es una institución muy bien administrada.

A FIFA parece ser uma boa instituição para se trabalhar. A FIFA é uma instituição que parece ter bons funcionários

A FIFA apóia boas causas.

A FIFA é uma instituição ambientalmente responsável.

A FIFA mantém um alto padrão na forma como ele trata as pessoas.
La FIFA parece una buena institución para trabajar.

La FIFA se parece a una institución que tendría buenos empleados.

\section{La FIFA apoya buenas causas.}

La FIFA es una institución ecológicamente responsable. trata a las personas.
La FIFA mantiene un alto estándar en la forma en la que
(BRAND) and the World Cup stand for similar things.

It makes sense to me that (BRAND) sponsors this World Cup.

It makes sense to buy (BRAND) instead of any other brand. even if they are the same.

Even if another brand has the same features as (BRAND) I would prefer to buy (BRAND).

If there is another brand as good as (BRAND). I prefer to buy (BRAND).

If another brand is not different from (BRAND) in any way. it seems smarter to purchase (BRAND).

FIFA awakens positive feelings.

FIFA is worthy of admiration and respect.

FIFA is trustworthy.

FIFA has excellent leadership.

FIFA has a clear vision for its future.

FIFA recognizes and takes advantages of market opportunities.

FIFA is well managed.

FIFA looks like a good institution to work for.

FIFA looks like an institution that would have good employees.

FIFA supports good causes.

FIFA is an environmentally responsible institution.

FIFA maintains a high standard in the way it treats people. 